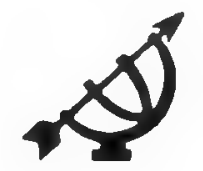

\title{
Religious paradoxes in Graham Greene's novels
}

I began to believe in heaven because I believed in hell (Graham Greene $\mathbf{1}^{\mathbf{1}}$ )

\author{
Nettie Cloete \\ Department of English Studies \\ University of the North \\ SOVENGA
}

\section{Abstract \\ Religious paradoxes in Graham Greene's novels}

Graham Greene's work, especially his major novels, reveals his probing interest in religious matters. His writing indicates that throughout his career he has found himself involved in essential - and ofien paradoxical - questions concerning religious faith, particularly as these questions impinge on the twentieth-century mind. In this article some of Greene's paradoxical views on religious matters are explored in a more universal and anti-institutional context than the strictly Roman Catholic one in which his work is usually examined. As exemplars of Greene's work in which religious paradoxes are central, Brighton Rock, The Power and the Glory and Monsignor Quixote are discussed.

This article underscores the fact that Greene has almost single-handedly redefined twentieth-century Roman Catholic notions on piety with his constant revelation that pious people often lack charity while salvation is possible for sinners. It also shows that Greene's novels radically question the doctrines on morality espoused by conventional churches, thereby displaying his own religious sensitivity and courage.

Graham Greene (1904-1992) established his reputation as an entertaining and accomplished wnter, known for his literary adroitness and flair for story-telling. His career was long and prolific. Greene published for more than half a century, a rare achievement indeed. In all, over forty works in different genres, flowed from his pen. He is in fact one of the few twentiethcentury authors with an international audience 


\section{Contextualization}

Greene's work, especially his major novels, reveals his probing interest in religious matters. His writing indicates that throughout his career he has found himself involved in essential - and often paradoxical - issues concerning religious faith, particularly as these issues impinge on the twentieth-century mind ${ }^{2}$. His major novels thus constitute a substantial documentation of man's spiritual condition in the twentieth century. They portray people who, caught in the turmoil and flux of modern events, and wrought to the limits of their spiritual strength, exist in states between belief and unbelief, hope and despair, commitment and uncommitment, and who solitary, and unsure, victims of their times as they are, seem often to be echoing D.H. Lawrence's cry of anguish and despair: "Give us gods, O give them us".

Although most of Greene's major characters are or were Catholics, this does not make the author a "Catholic writer", one who expounds or promotes the doctrines of Catholic teaching, as many critics have tended to label him. Greene himself repeatedly and adamantly denied being a "Catholic writer", because such a classification limits the scope of his vision and casts doubt on the objectivity of his work. Despite Greene's own protestations about not being a Catholic writer, Owen Williams (1997:7) in a recent review still maintains that "[a]lthough this was very far from his intention, he became in his lifetime the best-known Englishlanguage layman of the Catholic Church"3

Nevertheless, Greene's career can usefully be divided into three periods: the preCatholic period, the Catholic period, and the post-Catholic period, a tripartite arrangement, however, that is neither clear-cut nor exclusive. The belief, held by many critics, that the novels reflect Greene's own religious stance and coincide with his active participation in Roman Catholicism or his withdrawal from it, is refuted by the fact that all the novels of the so-called "pre-Catholic period" appeared after Greene had joined the Catholic church in 1926. On the other hand, the first of the "Catholic novels", Brighton Rock, was published in 1938 - twelve years after Greene had become a Catholic.

2 The extremely brief introduction to the obituaries to Graham Greene in Contemporary Literary Criticism (Anon, 1992:285) singles out religious interest as the hallmark of Greene's work: "Greene was renowned for exploring religious themes in his work".

3 Cf. Also the view expressed in The New York Times (Anon., 1992:290)

"Greene was often labelled a Roman Catholic writer, a desciption which annoyed him but nevertheless coloured understanding of his work Hy was indeed a convert to Catholicism and he did deal with doctrinal issues, but he insisted that he was not a church publicist." 
The division into these three periods may, nevertheless, be made because of discernible differences in Greene's approach to religious matters in the various periods. In the novels of his pre-Catholic period, religious concerns do not play as prominent a part as in, for instance, the four major novels of the Catholic period. The delineation of religious concerns, often of a paradoxical nature, finds its fullest and most varied expression in the so-called Catholic period. In the novels of the so-called post-Catholic period the conflict widens to encompass a conflict between commitment and uncommitment, involvement and uninvolvement, or vacuity as opposed to the need for some kind of faith. Paradox strongly underpins even Greene's last works, as Travels with my Aunt (1969) and the shorter novel, Monsignor Quixote (1982), amply demonstrate.

\section{Religious paradoxes in three novels by Graham Greene}

In her doctoral thesis, Paradox in the Novels of Graham Greene (1991:ii) Ingrid Bonanni traces in Greene's autobiographical works his "lifelong interest in paradox and his duality on most issues", a duality which she rightly ascribes to his unhappy youth. Greene's first twelve years were relatively happy until he became a boarder at Berkhamsted school where his father was headmaster. He could not adapt to a situation where home and school were under one roof. Bonanni (1991:1) usefully defines paradox, and especially Greene's use of it, as follows:
... this is the nature of paradox: as an apparent contradiction in terms, to use the well-worn definition, it raises issues that defy simple resolution. Paradox, specifically the often clashing paradoxes that Greene employed in his novels, finds its end, not in any reconciliation of opposed issues, but rather in realising the irreconcilibility of fundamental conflicts. The final answer, then, is that there is no final answer. Or if there is one, only God knows it.

In this article I intend exploring some of Greene's paradoxical views on religious matters in a more universal and anti-institutional context than the strictly Roman Catholic one in which his work is usually examined. As exemplars of Greene's work in which religious paradoxes are central Brighton Rock, The Power and the Glory and Monsignor Quixote will be discussed.

\subsection{Brighton Rock4 (1939)}

Although Brighton Rock, the first novel of Greene's so-called Catholic period, can be read as a detective story, it is "almost belligerently religious in theme" (Stratford, 1967:166). This novel was a turning point for Greene in that he had discovered that "a Catholic is more capable of evil that anyone" (BR:309), since,

4 Brighton Rock - henceforth referred to as BR. 


\section{Religious paradoxes in Graham Greene's novels}

in the words of McGowan (1955:27), "he reached the distinction of good and evil from right and wrong", in itself a paradoxical metaphysical statement, underpinning once again Greene's profound, but essentially anguished, wrestling with (paradoxical) religious concepts.

In Brighton Rock, like in the novels of the pre-Catholic period, Greene again depicted a fallen world and unheroic characters without condemning them for their forfeit of grace. The plot centres in the actions of the seventeen year-old Pinkie Brown, the leader of a racing gang, and his efforts to conceal a murder. In the process he marries an innocent girl, Rose, to prevent her from giving evidence against him in court. He makes a suicide pact with Rose from which he intends withdrawing after her death. Ida, a goodtime girl, catches up with the couple in time to save Rose. This causes Pinkie to commit suicide by throwing vitriol over himself and then jumping over the cliffs, dying a terrible death.

The three main characters themselves reflect conflicting attitudes. Ida believes in life, Rose in religion, while Pinkie reveals a conscious willed unbelief. Pinkıe, however, constitutes the novel's real religious paradox. He believes, but sets himself up against his belief. His is the tragedy of a Faustus, though on a smaller scale, a man who knows which way salvation lies and yet deliberately opposes himself to Divine injunctions. He tries to assert his own individuality, his own ego and personality, against Divine authority. For example, he believes in hell rather than in heaven: "Heaven was a word: hell was something he could trust" (BR:284). Greene ironically adapting Wordsworth, states: "hell lay about him in his infancy" (BR:81). Yet, despite all Pinkie's efforts to deny his faith, he cannot get rid of his Roman Catholicism, which in its music and rituals, for instance, constantly affects his thoughts and deeds.

Greene himself regarded the mysteriousness of Divine grace as the theme of this novel:

Brighton Rock is written in such a way that people could plausibly imagine that Pinkie went to hell, and then I cast doubt upon it in the ending. The real theme ... is embodied in the priest's phrase at the end of Brighton Rock: 'You can't conceive, my child, nor can anyone, the ... appalling strangeness of the mercy of God' (Philips, 1973:173)

A reader who understands Greene's preoccupation with the paradoxical nature of religion, as well as with the anti-hero, a man stripped of all his finery and superficial civilisation, will not regard Pinkie as beyond God's mercy. It may therefore be conceded that, however evil his life might have been, his earthly destruction may lead to his spiritual resurrection. In this regard Greene shows an affinity with the seventeenth-century Jansenists, whom McEwan (1988:14) regards as "somewhat heretical Catholics" who stressed that only the "completely mysterious workings of divine grace" can save human beings from hell. The 
Priest tries to console Rose when she goes to confession after Pinkie's death by reminding her of Pèguy, who could not "bear the idea that any soul could suffer damnation" (BR:308). He also remarks "We must hope and pray ... hope and pray. The Church does not demand that we believe any soul is cut off from mercy" (BR:308).

To conclude, Brighton Rock marked a new literary direction for Greene. Here, more distinctly than in the previous novels, the conflicts between belief and unbelief come into focus, and the many facets of these conflics, the ironic ambiguities and paradoxes, are examined and evaluated more intensely and satisfyingly than ever before.

\subsection{The Power and the Glory5 (1940)}

Greene's next novel, The Power and the Glory, "a pre-eminently religious novel" (Lamba, 1987:58), exposes conditions in Tabasco, a small state in Mexico, where priests were persecuted with pitiless cruelty by the totalitarian, anti-religious regime which took over the province in 1917. The central opposing characters are an unnamed Whisky Priest, who sometimes assumes the name Montez, and a similarly unnamed Lieutenant of the Police. The Power and the Glory is divided into four parts. The first introduces the Whisky Priest, who has been a fugitive for eight years, while trying to escape from the country where he has remained as the last priest, following the execution or defection of the others. The second part shows the Priest's return to his native village, where he meets his illegitimate daughter, Brigitta, and narrowly escapes arrest by the Lieutenant. The Priest is later arrested for breaking the anti-liquor laws and spends a night in prison. The third part chronicles the Priest's betrayal by the mestizo who wants to get a reward promised by the Lieutenant. The fourth part of the novel reports the last conversation between the Priest and the Lieutenant before the Priest is executed.

Significantly, The Power and the Glory resembles Greene's preceding works, especially Brighton Rock. The theme of pursuit is again developed against a vividly authentic background which, because of the violence and poverty that are to become increasingly typical of Greene's fallen world, critics have dubbed "Greeneland" - much to Greene's own dismay. Nevertheless, in The Power and the Glory the theme of pursuit takes on a deeper significance than in Brighton Rock.

In the later novel the Priest serves as the main embodiment of belief and the Lieutenant of unbelief or atheism. The fact that both are nameless indicates the universality of the conflict they represent. In his early criticism of the novel De

5 The Power and the Glory - henceforth referred to as PG 
Religious paradoxes in Graham Greene's novels

Vitis (1964:89) rightly regarded The Power and the Glory as a consistent allegory on the theme of Everyman, while Karl Patten (1957:233) commended Greene for his increasing symbolism: "if the priest is an Everyman who is to be related, by suggestion, to Christ, then the Lieutenant is to be understood as a Saul of Tarsus".

The Priest himself is a paradoxical figure. Friedman (1990:136), for instance, notes in him a "double rhythm of hope and despair, action and passivity, vaunting ambition and victimization, longing for escape and for capture, obsession equally with the diurnal and the transcendent moment". In addition, Greene convincingly makes use of sustained paradox to contrast the Priest, an earthly, fallible human being, prone to the sins of all his parishioners and tending to relapse in performing his religious duties, with the Lieutenant, who leads a puritanical life and is dedicated to his secular ideals. No better description of the Priest's fall from grace can be given than that presented in his confession to the Lieutenant:

'That other priest was right. It was when he left I began to go to pieces. One thing went after another. I got careless about my duties. I began to drink. It would have been much better, I think, if I had gone too. Because pride was at work all the time. Not love of God .... Pride was what made the angels fall. Pride's the worst thing of all' (PG: 235-236).

Greene compounds the irony of the Priest's confession in that it is to the Lieutenant, the Priest's arch enemy, himself a proud man, and a committed unbeliever. Indeed, the Lieutenant is much more like an ideal priest than the Priest himself. Greene emphasizes the Lieutenant's chastity, honesty, asceticism, and dedication: his room is like "a monastic cell" (PG:23), "[h]imself he felt no need of women" (PG:21); and there "was something of a priest in his intent observant walk - a theologian going back over the errors of the past to destroy them again" (PG:23).

The creation of the Lieutenant is one of Greene's finest achievements. Dedicated, high-minded, he is a worthy opponent of the Priest. His actions are selfless and in a paradoxical sense impeccably moral, as an abstract of his aims illuminates:

... it was for these [the children] he was fighting. He would eliminate from their childhood everything which had made him miserable, all that was poor, superstitious and corrupt. They deserved nothing less than the truth - a vacant universe and a cooling world, the right to be happy in any way they chose. He was quite prepared to make a massacre for their sakes - first the Church and then the foreigner and then the politician (PG:65).

However, even in the moments of the Priest's degradation, as in the prison scene, Greene underscores the indestructibility of the Priest's faith, as opposed to the awareness of lack of faith in the Lieutenant: 
It infuriated him to think that there were still people who believed in a loving and merciful God. There are mystics who are said to have experienced God directly. He was a mystic, too, and what he had experienced was vacancy - a complete certainty in the existence of a dying, cooling world, of human beings who had evolved from animals for no purpose at all. He knew (PG:23).

The Lieutenant's noble idea to create a just society is in itself paradoxical: his endeavours to establish a just and peaceful society simply lead to suffering and cruelty. The Lieutenant, however, cannot be regarded as unfeeling. His harshness results from his belief that the church is directly accountable for the unjust society. He sees in the priesthood a corrupt system which favours only the few, and because he wants to wipe out clericalism, he orders the taking and shooting of hostages. Yet he is simultaneously capable of charity, as in his offer to allow Padre José hear the Priest's confession. The Priest, on the other hand, expresses the theodicy of the novel when he argues in a sermon to the persecuted Christians that suffering and pain have to be endured on earth to move us nearer to the ultimate and all-inclusive good: "He was talking about heaven, standing between them and the candles in the ragged peon trousers and torn shirt ... He said: 'One of the Fathers has told us that joy always depends on pain. Pain is part of joy"” (PG:79).

Conversely, the Lieutenant's pursuit of the church arouses a feeling of compassion in the Priest; for example when in the darkness and stench of the prison, "[h]e was moved by an enormous and irrational affection for the inhabitants of this prison. A phrase came to him: 'God so loved the world .." (PG:151). He is no longer proud and smug: "He had a sense of companionship which he had never experienced in the old days when pious people came kissing his black cotton glove" (PG:153). Then he felt "no pity at all" (PG:157), but "in his corruption" (PG:166) he learns.

Significantly, the Lieutenant serves to ennoble the Priest by stopping the latter's further degradation and forcing him to recognize his own weaknesses. Moreover, in his last moments the Priest realizes that he has failed his mission on earth, but in this realization he achieves his spiritual apotheosis: "Tears poured down his face; he was not at the moment afraid of damnation - even the fear of pain was in the background. He only felt an immense disappointment because he had to go to God empty-handed, with nothing done at all" (PG:253). With the Priest's death at the end of the novel, Greene deftly resolves the conflict between the two protagonists. When the Priest dies and the Lieutenant seems to be victorious, we have the inversion, the arrival of a new priest. The church triumphs and the title of the novel asserts itself: for Thine is the Kingdom, the Power, and the Glory.

The Power and the Glory is a remarkable achievement, in the words of John Updike (1990:16): "The Power and the Glory is generally agreed to be Graham 
Greene's masterpiece, the book of his held highest in popular as well as critical esteem". There is not perhaps any development of character: the Whisky Priest and the Lieutenant are fixed in their mould from the beginning. They are, however, convincingly drawn and their actions motivated. The Whisky Priest comes alive as a tenacious man of God, despite his frailties and abject condition, while the Lieutenant is presented as a high-minded ascetic, dedicated to his radical mission in life. It is indeed a moving and thought-provoking novel.

\subsection{Monsignor Quixote (1982)}

The short later novel, Monsignor Quixote, recalls many aspects of Greene's earlier work. It shows a close affinity with especially The Power and the Glory in that it again allows a degraded priest to triumph over his rivals, in this instance over high-minded and learned clergymen who lack real compassion. Moreover, paradox may once more be regarded as this novel's cornerstone. In the words of Amaracheewa (1982:iii), this novel evinces the paradoxical fact that "Greene's good characters are explicitly the ones who are guided by an inner love and ethic despite the surface appearance of despair and damnation, whereas his bad characters consciously appear to seek moral conduct in conventional piety".

Greene's use of the Shakespearean quotation as an epigraph to the novel "There is nothing either good or bad, but thinking makes it so" - underscores his intention to reveal religious paradoxes in the novel. In the words of Bonanni (1991:84) "sinful mankind reads evil into the motives of others; appearance is interpreted as reality and the outward shown as the inward intention".

In Monsignor Quixote6 Greene examines the "antithetical compromise" (Bonanni, 1991:4) between the Communist ex-mayor, Sancho, and his friend, an ordinary but widely read village Priest who is promoted to monsignor as a result of his charity to an Italian bishop. The novel relates how Quixote and Sancho embark on a journey in Rocinante, the Priest's old ramshackle car, his only passion in life. When the novel opens the Bishop scorns Quixote's lack of nobility, mediocre religious instruction and ridiculous claim to be a descendant of a fictional character. On the journey Quixote and Sancho are constantly in trouble with the authorities. Moreover, Quixote enrages the Bishop by his remark "Bugger the Bishop" (MQ:156) and is ordered to return to El Toboso to account for his deeds. The second part of the novel relates how Sancho rescues Quixote from the Bishop's arrest and depicts the continuation of their journey during which the Priest performs a couple of courageous deeds, like his fictional ancestor. The Guardia recapture them, in the process seriously injuring Mon- 
signor Quixote and gunning down his beloved Rocinante. Quixote is taken to a Trappist monastery where he, in his delirium, insists on performing a strange mass for Sancho. The novel ends with the Priest dying at the altar, leaving Sancho, the hitherto staunch Communist, experiencing an unusual feeling of love for the Priest who has so radically changed his life.

The ensuing discussion of religious paradox in this novel will examine two areas - first the paradoxical nature of both religion and Communism, and second, religious paradoxes in Catholic officials. It is, however, always clear that Greene distinguishes between his clergy and the Church itself - while Catholic clergymen are often corrupt in the execution of their duties, the Church is not shown as such.

The literary discussions between Quixote and Sancho reveal that Quixote understands and sympathizes with Marx, while Sancho in turn reveals an interest in the Priest's often scorned and outdated Christian authors. Because they are both seeking answers and are willing to question accepted beliefs, they have empathy with each other, as the following passage reveals:

Finally, under the ruined wall of an outhouse, which belonged to an abandoned farm, they found what they needed. Someone had painted a hammer and sickle crudely in red upon the crumbling stone.

'I would have preferred a cross,' Father Quixote said, 'to eat under.'

'What does it matter? The taste of cheese will not be affected by cross or hammer. Besides, is there much difference between the two? They are both protests against injustice.'

'But the results were a little different. One created tyranny, the other charity.'

'Tyranny? Charity? What about the Inquisition and our patriot Torquemada?' (MQ:41-42).

In the early stage of the journey the Priest reflects on the strange, paradoxical bond between them:

It's odd, he thought, as he steered Rocinante with undue caution round a curve, how sharing a sense of doubt can bring men together even more than sharing a faith. The believer will fight another believer over a shade of difference: the doubter only fights with himself (MQ:52).

He even tells Sancho: "perhaps a true Communist is a sort of priest" (MQ:91).

Neil McEvan (1988:134) regards Monsignor Quixote as "a good innocent because he is an unsuccessful, unambitious priest, who lives humbly with the knowledge that he is somewhat ridiculous". For the Priest, like for so many of Greene's characters, faith is constantly shadowed by doubt as he admits to Sancho: "Oh, despair I understand. I know despair too, Sancho" (MQ:43). 
The Priest possesses the qualities which Greene views as essential for a good man: the ability to acknowledge humility and doubt, coupled with a sense of compassion for other people. He himself tells Sancho: "I know I'm a poor priest errant, travelling God knows where. I know that there are absurdities in some of my books ... [but] I still have faith." Father Quixote's compassion for mankind is evinced in his willingness to say a prayer even for Judas or Stalin.

In Greene's framework, Sancho should paradoxically also be seen as a good man because he admits that he has weaknesses while simultaneously showing understanding for another person's beliefs, as his attitude towards the Priest constantly exhibits. After the strange Mass, Sancho explicitly tells Father Leopoldo: "But I'm afraid in the eyes of your Church I'm a very unworthy recipient. I am a Communist. One who has not been to confession for thirty years or more. What I've done in those thirty years - well, you wouldn't like me to go into details" (MQ:219). Father Leopoldo, however, expresses Greene's paradoxical view of sin and redemption by retorting: "You were a good friend and you are a good man" (MQ:220).

However, no trace of Greene's usual comic tone which characterises the conversations between the Priest and Sancho, is found in his descriptions of the socalled "intellectual Catholic activists" (MQ:61), as the incident relating the buying of the purple socks indicates. Father Quixote's dismay with the exuberance of the shop is only too obvious:

His heart sank as he took in the elegance of the shop and the dark well-pressed suit of the assistant who greeted them with the distant courtesy of a church authority. It occurred to Father Quixote that such a man was almost certainly a member of the Opus Dei - that club of intellectual Catholic activists whom he could not fault and yet whom he could not trust. He was a countryman, and they belonged to the great cities (MQ:61)

The Priest's own Bishop and Father Herrera, the ambitious young clergyman clearly marked as the Monsignor's successor, are also used as vehicles of Greene's paradoxical views on religion. The Bishop displays neither compassion nor understanding. When he is instructed to inform the Priest that he has been promoted to monsignor on the recommendation of the Italian Bishop, Quixote immediately senses that "the letter seemed to have been written in a cold rage" (MQ:25). The letter reveals this Bishop as self-seeking and cold: he writes that he has been asked

... to promote you to the rank of Monsignor, apparently on the recommendation of a Bishop of Mutopo, of whom I have never heard, without any reference to me, through whom such a recommendation should naturally have come - a most unlikely action on my part, I need hardly add (MQ:25). 
Greene's irritation with uncharitable dogma is evident in Monsignor Quixote's recollection of a "rather silent dinner" (MQ:64) he had spent with Father Hererra when he had felt "that he could never communicate with Father Herrera on anything which touched the religion they were supposed to share" (MQ:64). Greene compounds the irony inherent in the situation by remarking: "Perhaps Father Herrera was hoping for a truly heretical reply which could be reported - of course by the proper channels - to Rome" (MQ:65). This arrogant young clergyman who flaunts his Doctorate in Moral Theology also lacks humanity. On his arrival he is immediately offended by Teresa's behaviour, refuses to drink coffee because it keeps him awake at night but "[i]n the sitting-room Father Herrera took the only armchair without hesitation" (MQ:65).

It is thus evident that in Monsignor Quixote Greene constantly applies paradox to reveal inconsistencies in the attitude of clerics, thereby advocating a reconsideration of religion which relies solely on doctrine but which lacks Christian compassion.

\section{Conclusion}

To conclude, this article has underscored that Greene has almost single-handedly redefined twentieth-century Roman Catholic notions on piety with his constant revelation of the essential paradox that "the greatest saints are the people with more than a normal capacity for evil, and the most vicious people only escaped sanctity with the greatest difficulty" (Simon, 1952:75). Simon's early observation may be extended to view Pinkie, the Whisky Priest, and to a lesser degree Monsignor Quixote and Sancho, as characters who are touched with grace, while the Lieutenant as well as the Bishop and Father Herrera should be seen as devoid of charity and compassion. This paradoxical view of characters is quite convincing, although "uncomfortable" (McEwan, 1988:14). Greene has thus contributed to the idea of a new humble, "imperical" Roman Catholic Church.

These novels also reveal that Greene's commitment is to life, life lived to the full and not to a sterile, dogmatic kind of life. Greene constantly attacks selfrighteousness, thereby displaying his own religious sensitivity and courage. Greene's novels thus radically question the doctrines on morality espoused by conventional churches.

I agree also with Sharrock's (1984:82) view that in Greene's novels "there is always a tension, a peculiarly English tension, not simply between the world and the spirit, but between two equally balanced and desperately antagonistic points of view". This tension between paradoxical values is noticeable in the work of a vast number of English writers, for instance Joseph Conrad, D.H. Lawrence, James Joyce, and William Golding. In other words, Greene has throughout his literary career employed paradox to reveal the density and duality of morality and 
ethics. His novels thus "extend and clarify our understanding of the world of his imagination ... [while] they furnish a coherent view of human nature in all its paradoxes and contradictions" (Sherry, 1989:228). In the words of Salvatore (1988:15) Greene's "characters speak so that the reader may perceive and weigh the advantages and disadvantages of many different life categories".

That paradox lies at the heart of Greene's artistic portrayal of life is vindicated by the fact that Greene himself suggested the following lines from Bishop Blougram's Apology as an epigraph for all his novels:

Our interest's on the dangerous edge of things

The honest thief, the tender murderer,

The superstitious atheist, demi-rep

That loves and saves her soul in new French books -

We watch while these in equilibrium keep

The giddy line midway

\section{Bibliography}

ANON. 1992. The New York Times. Contemporary Literary Criticism, XXV:290

AMARACHEEWA, AMPORN. 1982. Graham Greene's Paradoxical Views of Morality: The Nature of Sin. Ohio : Ohio Bowling Green State University. (Ph D thesis.)

BONANNI, INGRID. 1991. Paradox in the Novels of Graham Greene. Pretoria : University of South Africa. (Ph D thesis.)

CHAMPNESS, H.M. 1955. “A New Novel”. Spectator, CXCV:820, Dec. 9.

DE VITIS, A.A. 1964. Graham Greene. New York: Twayne Publishers.

FRIEDMAN, J. 1990. The Dangerous Edge: Beginning with Death. (In Meyers, J ed. Graham Geene: A Revaluation. London : MacMillan. )

GREENE, G. 1938 [1975]. Brighton Rock (BR). London . Heinemann \& Bodley Head

GREENE, G. 1940 [1979]. The Power and the Glory (PG). London : Heinemann \& Bodley Head.

GREENE, G. 1982. Monsignor Quixote (MQ). London : Bodley Head

LAMBA, B.P. 1987. Graham Greene: His Mind and Art. New York : Apt Books Inc

McEWAN, N. 1988. Modern Novelists. Graham Greene. New York : St. Martins Press.

McGOWAN, F A. 1955. Symbolism in Brighton Rock. Ranascence, VIII 25-35, Autumn

PATTEN, K. 1957. The Structure of The Power and the Glory. Modern Fiction Studies, III:225-234, Autumn.

PHIIIPS, G.D. 1973. Graham Greene: On the Screen. (In Hynes, S. ed Graham Greene: A Collection of Critical Essays. London : Prentice Hall )

SALVATORE, ANNE T. 1988. Greene and Kierkegaard: The Discourse of Belief London University of Alabama Press.

SHARROCK, R. 1984. Saints, Sinners and Comedians: The Novels of Graham Greene. Kent Burns \& Oates

SHERRY, N. 1989. The Life of Graham Greene. Vol. I. London : Penguin

SIMON, F.J.W. 1952. Salvation in the Novels. Commonweal, LVI, April 25.

STRATFORD, P. 1967. Faith and Fiction: Creative Process in Greene and Mauriac. Paris University of Notre Dame Press 
UPDIKE, J. 1990. The Passion of Graham Greene. The New York Review of Books, XXXVII: 16-17, August 16.

WILLIAMS, O. 1997. Graham Greene revealed as a writer of the soul. The Southern Cross: 7, Nov. 23. 